\title{
Ballistic resistance of bulletproof vests level IIIA. Development of testing methodology
}

\author{
Svetlana Yaneva \\ Technical University of Sofia, Faculty of Mechanical Engineering, Department of Fundamentals and Technical Means of Design, \\ Bulgaria
}

\begin{abstract}
This study presents the process of development of a methodology for testing the ballistic resistance of bulletproof vests. The methodology is especially intended for testing bulletproof vests with protection level IIIA, according to NIJ 0101.04. This level provides an adequate protection of the life and health of anti-terrorists, police and security officers at duty considering the most common potential threats. The methodology is based on the requirements and norms for the given level of protection laid down in the standardization documents in this field, namely NIJ Standard-0101.04 - Ballistic Resistance of Personal Body Armor, NIJ Standard-0101.06 - Ballistic Resistance of Body Armor, STANAG 2920 - Ballistic test methodology for personal armour materials and combat clothing, GOST R 50744-95 - Armored clothing, as well as these of Ministry of Defence and Ministry of Interior of the Republic of Bulgaria. In the process of its development, the principles of comparison, compliance and analysis have been used, taking into account the typical specifics and specification of the weapons and their ammunition used in the Balkan region. Testing methods include the most common ammunition in the Balkans. In this way, the bulletproof vests tested on it would provide a more adequate level of protection, thus reducing the possibility of injuries of the officers in the course of their assigned tasks. Used to evaluate the ballistic resistance of bulletproof vests with a level of protection IIIA, the proposed methodology is quick and adequate, in line with identified potential threats by certain weapons used in the Balkans.
\end{abstract}

\section{Introduction}

The bulletproof vest is an individual protection feature made in the shape of a vest that protects the torso of the human body completely or partially by stopping or reducing the harmful effects of a cool weapon, firearm solid bodies, projectiles, grenades, and other types of ammunition. It is a compulsory part of the individual equipment of the anti-terrorist $[1,2]$.

The modern multi-component bulletproof vest is made of various combination of special protective materials (p-aramides: $\operatorname{Kevlar} \AA$, Twaron $\AA$, Artec $\AA$, maramides: Nomex $\AA$, Kermel $\AA$, Teijinconex $\AA$, Kynol $\AA$ UHMWPE Ultra-high molecular weight polyethylene: Dyneema ${ }^{\circledR}$, Spectra ${ }^{\circledR}$, PBO-poly (p-phenyllene-2,6benzobisoxazole): Zylon $\AA$, Polyhydroquinonediimidazopyridine: $M 5 \AA$, etc.) made in the form of fibres and fabric. Composite and different types of ceramic materials (oxide, carbide, boron nitride and mixed ceramics) are also used which, due to their high stiffness and low density, are preferred for the manufacture of armoured panels [3]. Due to their specific physiochemical properties, these materials distribute and absorb the kinetic energy of the fired bodies and the targeted puncture objects, protecting the human body.
The total defensive area of the bulletproof vest must provide effective ballistic protection of the vital organs at a level of not less than $90 \%$. It must stop the fired solid body or splinters, with minimal deformation on the rear, to minimize possible impact injuries. In order for such a high level of protection to be achieved, the fire protection features of the bulletproof vests must be thoroughly checked and evaluated before compliance with the requirements and criteria laid down in any of the applicable standards in this field. For this purpose, depending on the desired protection level, the armour plates are subjected to a series of tests.

At present, there is a wide variety of different types of bulletproof vests, tested and certified by some of the most commonly used standardization documents, such as:

- Standards of the United States National Institute of Justice - NIJ 0101.04. Ballistic Resistance of Personal Body Armour [4] and NIJ 0101.06. Ballistic Resistance of Body Armour [5];

- National Standard of Russia - GOST R 50744-95 Armoured clothing [6];

- German standards - German Schutzklassen. Bullet Resistant Vests with stab protection 2003 and VPAM. PERSONAL ARMOUR [7];

- Ballistic protection standards for police in the UK PSDB. Body Armour Standards for UC Police 
(2003) Part 2. Ballistic Resistance [8] and PSDB. Portable Ballistic Protection Standard for UC Police [9], as HOSDB Body Armour Standards for UK Police (2007), Part 1: General Requirements [10] and HOSDB Body Armour Standards for UK Police (2007) [11];

- NATO Standardization Agreement - STANAG 2920, Ballistic Test Methodology for Personal Armour Materials and Combat Clothing [12].

The standards examined, defining security levels and testing procedures, use test ammunition in line with the weapons used in their countries and their adjacent regions. The Balkan countries, as a crossroads in the past and in the Cold War, participate with the countries of the European Community in establishing the Council for Mutual Economic Assistance. Military-political organizations were created, respectively, the Western Bloc countries - the North Atlantic Treaty Organization, and the Eastern Bloc countries - the Warsaw Treaty Organization. Later after the collapse of the Council for Mutual Economic Assistance, part of the Balkan countries became members of NATO. When moving from one organization to another in the Balkans, weapons remain mostly Russian, European, American, and others. An important element in conducting ballistic resistance tests is the knowledge of the weapons used in the region and their introduction as test ones.

In the proposed test methodology, the ballistic resistance of ballistic missiles with level of protection IIIA, the requirements of NIJ 0101.04, GOST R 5074495 and STANAG 2920 have been applied, taking into account the typical weapons and ammunition used in the Balkans.

The methodology has been developed for Level IIIA as it is one of the most used and provides adequate protection for the health and life of antiterrorists, police and security authorities in the course of their duties, according to the degree of the most frequent potential threats.

\section{Methodology for testing the ballistic resistance of bulletproof vests with protection level IIIA}

The methodology is designed to check the adequacy (with respect to ballistic resistance) of a bulletproof vest with a level of protection IIIA, without additional hard inserts, providing $99.99 \%$ protection of the front and back of the torso of the fighter / policeman from direct hits and rebounds of gun bullets used in three of the leading standardization papers in this area to take into account the specificities of the weapons used in the region.

The level of protection provides a general definition of the types of threats to which the bulletproof vest must be sustainable.

The test is done through the main part of a bulletproof vest, consisting of a set of front and rear flexible ballistic panels, which are stationary in an outer case.
The purpose of the test is to verify the conformity of the physical and mechanical characteristics of a model of a bulletproof vest with the set standards.

In the process of elaboration of the methodology, the principles of comparison, compliance and analysis of leading in the field, normative documents [4 - 12] were used, taking into account the requirements of the Ministry of Defence and the Police of the Republic of Bulgaria [13,14].

In Figure 1. is shows the test polygon, used for testing the ballistic resistance of a bulletproof vest.

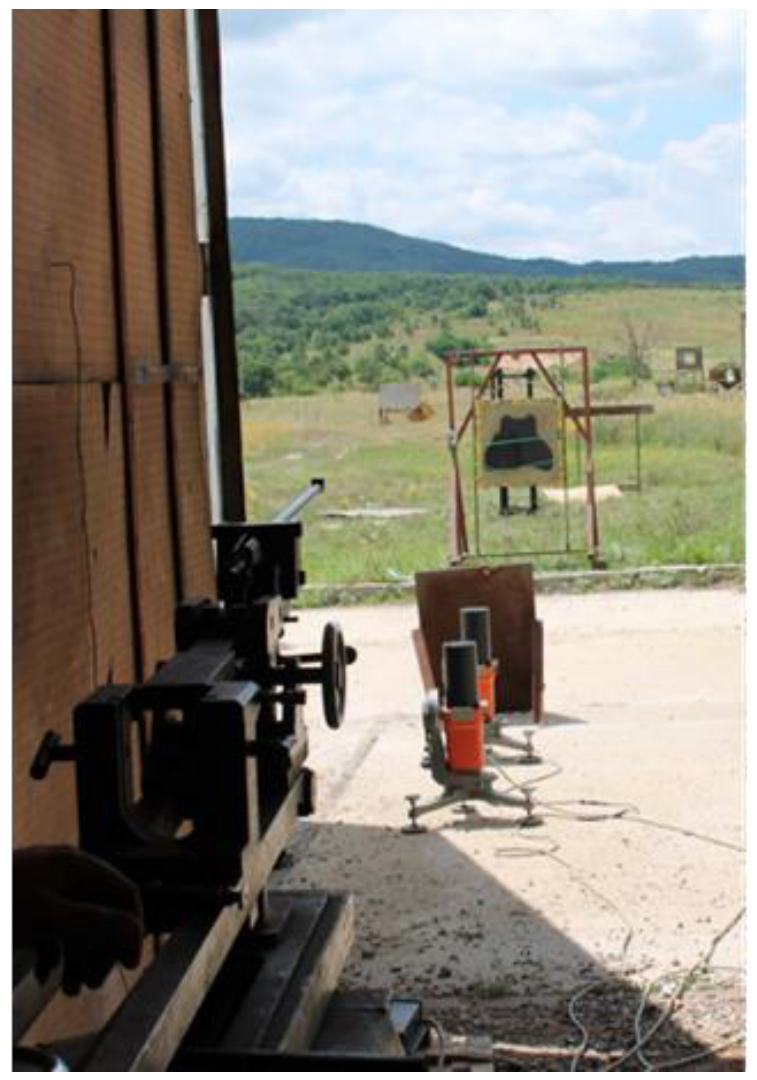

Fig. 1. Test the ballistic resistance of a bulletproof vest (Photographer S. Yaneva).

\subsection{Facilities and equipment}

The following facilities and equipment are required to perform the tests:

- Apparatus for measuring the initial velocity of the bullet to an accuracy of $\pm 0,3 \mathrm{~m} / \mathrm{s}$ or higher;

- Bearing structure for underlying material biological tissue imitator;

- Biological tissue imitator;

- Elastic fastening belts;

- Stool for attaching ballistic barrels;

- Weighing range up to $10 \mathrm{~kg}$;

- Calibrator with depth gauge with a range of 0 to 150 $\mathrm{mm}$;

- Calibrated roulette with a range of up to $50 \mathrm{~m}$;

- Ballistic barrels for cartridges with caliber: 9x19mm; .44 Magnum; .357 SIG

- $\quad$ Test cartridges: 9-mm FMJ RN; .44 Magnum SJHP; .357 SIG FMJ FN. 


\subsection{Terms and conditions for conducting the test}

The tests may be conducted in laboratory or polygonal conditions under the following environmental conditions:

- Temperature: $21^{\circ} \mathrm{C} \pm 5{ }^{\circ} \mathrm{C}$;

- Relative humidity: $50 \% \pm 20 \%$;

- No wind and rain (for polygon tests).

All specimen bulletproof vests which are going to be tested must be individually examined for damage, material defects or poor workmanship and staying at least 12 before the tests in the appropriate laboratory or polygon conditions for tempering.

\subsubsection{Preparation of the test field}

The test field (apparatus, equipment, additional materials) shall be prepared and packaged according to the layout scheme (Fig. 2) in accordance with the requirements of standard NIJ 0101.04.

The speedometer is brought to standby before the measurements are taken.

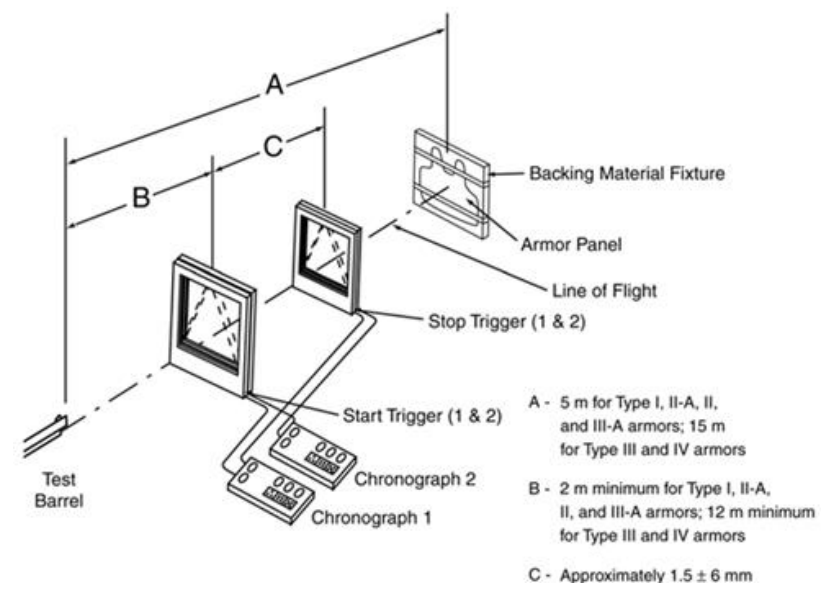

Fig. 2. Schedule of deployment of test polygon (NIJ 0101.04) [4]

\subsubsection{Marking the sample shooting locations}

The places where the shots will fall are marked on the bulletproof vest. They must be located in defined areas in accordance with the hit pattern (Fig. 3), at a distance of at least $76 \mathrm{~mm}$ from the edge of the test piece and a minimum distance of $51 \mathrm{~mm}$ between two separate hits. Shots may fall in any area shown, with the central part necessarily being used.
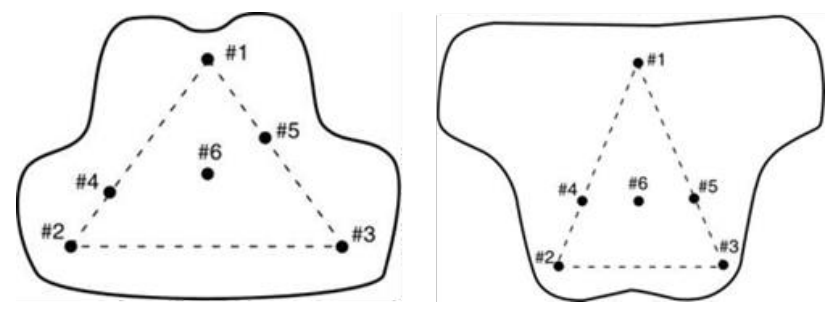

Fig. 3. Sample schematics of the admitted shots - front and back (NIJ 0101.04) [4].

\subsubsection{Attaching the bulletproof test sample}

The armoured vest sample being tested shall be fixed to the biological tissue imitator vertically, perpendicular to the direction of firing by means of elastic belts fitted so that they do not fall into the marked firing points.

\subsubsection{Conduct a series of ballistic stability tests for Level IIIA}

The necessary and sufficient minimum of samples of bulletproof vests to meet the ballistic resistance requirements for level IIIA is two whole bulletproof vests consisting of a set of front and rear flexible ballistic panels contained in an outer case or a total of four test panels. Each panel is made by six shots with four test cartridges with the corresponding characteristics and under the conditions specified in Table 1.

The test cartridges are carefully selected to cover the typical weapons used in the region, thus the armour wounds tested according to the present methodology will provide adequate protection for the given level with less risk of injuries to law enforcement personnel during execution of their assigned tasks.

Table 1. List of test ammunition and test conditions for bulletproof vests, level IIIA (S. Yaneva).

\begin{tabular}{|c|c|c|c|c|}
\hline $\begin{array}{c}\text { Test cartridge } \\
\text { № }\end{array}$ & № 1 & № 2 & № 3 & № 4 \\
\hline $\begin{array}{l}\text { According to } \\
\text { standard }\end{array}$ & $\begin{array}{c}\text { NIJ } \\
0101.04\end{array}$ & $\begin{array}{c}\text { NIJ } \\
0101.04 \\
\text { NIJ } \\
0101.06 \\
\end{array}$ & $\begin{array}{c}\text { NIJ } \\
0101.06\end{array}$ & $\begin{array}{c}\text { GOST R } \\
50744-95\end{array}$ \\
\hline $\begin{array}{l}\text { Name of } \\
\text { the cartridge }\end{array}$ & $\begin{array}{l}\text { 9-mm } \\
\text { FMJ RN }\end{array}$ & $\begin{array}{c}.44 \\
\text { Magnum } \\
\text { SJHP }\end{array}$ & $\begin{array}{l}.357 \text { SIG } \\
\text { FMJ FN }\end{array}$ & $\begin{array}{l}7,62 \times 25 \\
\text { FMJ RN }\end{array}$ \\
\hline $\begin{array}{r}\text { Type of } \\
\text { bullet }\end{array}$ & $\begin{array}{l}\text { Full } \\
\text { Metal } \\
\text { Jacket } \\
\text { Round } \\
\text { Nose }\end{array}$ & $\begin{array}{c}\text { Semi } \\
\text { Jacketed } \\
\text { Hollow } \\
\text { Point }\end{array}$ & $\begin{array}{c}\text { Full } \\
\text { Metal } \\
\text { Jacket } \\
\text { Flat } \\
\text { Nose }\end{array}$ & $\begin{array}{l}\text { Full } \\
\text { Metal } \\
\text { Jacket } \\
\text { Round } \\
\text { Nose }\end{array}$ \\
\hline $\begin{array}{l}\text { Bullet weight, } \\
\text { g }\end{array}$ & 8,0 & 15,6 & 8,1 & 5,5 \\
\hline $\begin{array}{c}\text { Bullet } \\
\text { velocity, } \mathbf{m} / \mathbf{s}\end{array}$ & $436 \pm 9$ & $436 \pm 9$ & $448 \pm 9$ & $440 \pm 9$ \\
\hline $\begin{array}{c}\text { Ballistic } \\
\text { barrel for } \\
\text { cartridges } \\
\text { with calibre }\end{array}$ & $\begin{array}{c}9 \mathrm{x} \\
19 \mathrm{~mm}\end{array}$ & $\begin{array}{c}.44 \\
\text { Magnum }\end{array}$ & $.357 \mathrm{SIG}$ & $7,62 \mathrm{~mm}$ \\
\hline $\begin{array}{c}\text { Number of } \\
\text { accepted shots } \\
\text { by one } \\
\text { ballistic panel }\end{array}$ & $\begin{array}{c}4 \text { hits - } 0^{\circ} \\
\text { NATO } \\
2 \text { hits - } \\
30^{\circ} \\
\text { NATO }\end{array}$ & $\begin{array}{c}4 \text { hits - } 0^{\circ} \\
\text { NATO } \\
2 \text { hits - } \\
30^{\circ} \\
\text { NATO }\end{array}$ & $\begin{array}{c}4 \text { hits - } \\
0^{\circ} \text { NATO } \\
2 \text { hits - } \\
30^{\circ} \\
\text { NATO }\end{array}$ & $\begin{array}{c}4 \text { hits - } \\
0^{\circ} \\
\text { NATO } \\
2 \text { hits - } \\
30^{\circ} \\
\text { NATO }\end{array}$ \\
\hline $\begin{array}{l}\text { Shooting } \\
\text { distance, } \mathrm{m}\end{array}$ & 5 & 5 & 5 & 5 \\
\hline $\begin{array}{l}\text { Permissible } \\
\text { depth of the } \\
\text { mark, mm }\end{array}$ & $\leq 30$ & $\leq 30$ & $\leq 30$ & $\leq 30$ \\
\hline
\end{tabular}




\subsection{Terms and conditions for conducting the test}

After each admitted hit, the bulletproof test specimen is carefully removed and thoroughly inspected for the damage caused by the bullet. The depth of the fingerprint obtained in the biological tissue imitator are measured and recorded in the test report (Fig. 4) along with the reported bullet rate; number of hit counts and impact of the bullet on the test specimen.

\section{PROTOCOL \\ TESTING THE BALLISTIC RESISTANCE OF BULLETPROOF VESTS, LEVEL IIIA}

\section{Environmental conditions}

Air temperature:

Relative humidity:

Description of the test sample

Composition:

Dimension:

Weight:

Test ammunitions

Cartridge:

Manufacturer:

Bullet type:

Bullet weight:

\begin{tabular}{|c|c|c|c|c|c|c|}
\hline $\begin{array}{c}\text { Shot } \\
\text { № }\end{array}$ & $\begin{array}{c}\text { Measured } \\
\text { bullet } \\
\text { velocity, } \\
\text { m/s }\end{array}$ & $\begin{array}{c}\text { Shooting } \\
\text { area }\end{array}$ & $\begin{array}{c}\text { Passed } \\
\text { bullets, } \\
\text { count }\end{array}$ & $\begin{array}{c}\text { Stopped } \\
\text { bullets, } \\
\text { count }\end{array}$ & $\begin{array}{c}\text { Shooting } \\
\text { angle, }\end{array}$ & $\begin{array}{c}\text { Mark, } \\
\text { mm }\end{array}$ \\
\hline 1. & & & & & $0^{\circ}$ & \\
\hline 2. & & & & & $0^{\circ}$ & \\
\hline 3. & & & & & $0^{\circ}$ & \\
\hline 4. & & & & & $0^{\circ}$ & \\
\hline 5. & & & & & $30^{\circ}$ & \\
\hline 6. & & & & & $30^{\circ}$ & \\
\hline
\end{tabular}

$\begin{array}{ll}\text { Passed } & \square \text { count } \\ \text { Stopped } & \square \text { count } \\ \text { Measured average speed } & \square \mathrm{m} / \mathrm{s} \\ \text { Calculated speed } & \square \mathrm{m} / \mathrm{s}\end{array}$

The values obtained meet the requirements (the false is crossed out)

\begin{tabular}{|l|}
\hline YES \\
\hline
\end{tabular}

Fig. 4. Ballistic resistance ballistic test report (S. Yaneva).
An admitted hit is a hit where the bullet falls into the test specimen at an angle of not more than $\pm 5^{\circ}$ of the desired shooting angle, not closer than $76 \mathrm{~mm}$ from the end of the ballistic panel and no closer than $51 \mathrm{~mm}$ to the previous stroke at a rate of impact not less than the required speed for the specified test bullet, according to table. 1 as well as a hit where the bullet has hit a distance of less than $76 \mathrm{~mm}$ from the edge of the test specimen or less than $51 \mathrm{~mm}$ from a previous hit or at a speed greater than the required speed but did not cause partial penetration or complete drilling of the test specimen and left a footprint on the imitator of biological tissue with a depth of less than $30 \mathrm{~mm}$. [4].

\subsection{Analysis and evaluation of results}

For each negative hit, a partial or complete perforation of the bulletproof sample pattern and a deformation with a fingerprint depth of more than $30 \mathrm{~mm}$ are accepted.

Partial or complete perforation of the bulletproof pattern as well as deformation with a fingerprint depth of more than $30 \mathrm{~mm}$ at a speed greater than the maximum indicated in Table 1 shall not be considered a hit and the result shall not be recorded in the record.

The absence of partial or complete perforation of the bulletproof sample and the presence of a deformation with a footprint of less than $30 \mathrm{~mm}$ at a speed greater than the maximum specified in Table 1 shall be considered a hit and the result shall be recorded in the record.

\section{Conclusion and evaluation}

The research and analysis of the various standardization documents revealed the lack of national standardization documents regulating the requirements for the individual ballistic protection means based on the potential threats typical of the country and the region.

Selection and use of one or another standardization document in the process of testing and certification body armour should be made based on the weapons used in the region, and revealed specific threats that may be different for different structures performing operations with different degree of risk.

The methodology is consistent with those used in the country and region specific weapons and their ammunition, thus bulletproof vests tested it and passed all the set requirements will ensure adequate protection for a given level and less risk of injuries to police officers, during the tasks assigned to them.

The methodology can be styled like a business standard applied in the process of testing the ballistic resistance of body armour protection level IIIA, and to serve as a fulcrum in the process of creating a Bulgarian national standard in accordance with the "Rules for national standardisation activities - Part 3: Drafting, Structure and Layout of Bulgarian Standards" [15].

Acknowledgements: The author would like to thank the Research and Development Sector at the Technical University of Sofia for the financial support. 


\section{References}

1. V. Nikolova, Prot. equ. us. in antiterr. oper. at airp. Proceedings of the project HOME/2010/CIPS/ $A G / 019$, Part 2, 45-50, ISBN: 978-954-92552-7-0, NNPH, Sofia (2013)

2. V. Nikolova, Special Means of Individual Protection. Scientific Monograph, ISCNC-BAS, ISBN: 978-619-90310-2-5, Sofia, Bulgaria (2014)

3. V. Nikolova, Mat. used in mak. the s. pan. of the bulletproof vest. Adv. and disadv. Conference Proceedings "Metal Science, Hydro- and Aerodynamics, National Security 2014", ISSN: 1313-8303, 405-409, Bulgaria (2015)

4. NIJ 0101.04. Ballistic Resistance of Personal Body Armor, (NIJ, Science and Technology, Washington, DC 20531, 2000)

5. NIJ 0101.06., Ballistic Resistance of Body Armor, (NIJ, Science and Technology, Washington, DC 20531, 2008)

6. GOST-R 50744-95 Armored clothing. Classification and general technical requirements, (State Standard of the Russian Federation, IPC, 2016)

7. German Schutzklassen, Bullet-Resistant Vests with Stab Protection, (Deutsches Institut für Normung, 2003)

8. J. Croft, PSDB Body Armour Standards For Uk Police. Part 2. Ballistic Resistance, Publ. No 7/03/B, AL4 9HQ, United Kingdom (2003)

9. J. Croft, D. Longhurst, PSDB Portable Ballistic Protection Standard For Uk Police. Incorporating Test Methods for Ballistic Blankets and Shields, Publ. No 34/04, Crown Copyright (2004)

10. J. Croft, D. Longhurst, HOSDB Body Armour Standards for UK Police, Part1: General Requirements, Publ. No.39/07/A, ISBN: 978-184726-424-4, Crown Copyright (2007)

11. J. Croft, D. Longhurst, D., HOSDB Body Armour Standards for UK Police (2007), Part 2: Ballistic Resistance, Publ. No. 39/07/B, ISBN: 978-1-84726425-1, Crown Copyright (2007)

12. STANAG 2920. Classification Of Personal Armour, (NATO Standardization agreement, North Atlantic Treaty Organization, NSA, 2015)

13. The Ministry of Defence of the Republic of Bulgaria. Armaments Council. Bulletproof Vest. Technical Specification, Sofia (2011)

14. Documentation for a public procurement contract for a framework agreement on "Supply of funds for individual ballistic protection", Sofia (2015)

15. BDS, Rules for national standardisation activities Part 3: Drafting, Structure and Layout of Bulgarian Standards, (Retrieved from http://www.bdsbg.org/bg/images/upload/Normativna\%20baza/BIS_ IR_3_2018.pdf) 